\title{
PENGEMBANGAN PERANGKAT PEMBELAJARAN MODEL INKUIRI TERBIMBING UNTUK MENINGKATKAN HASIL BELAJAR SISWA SEKOLAH MENENGAH PERTAMA
}

\author{
Susilo Mei Diawati' ${ }^{1)}$, Soeparman Kardi ${ }^{2)}$, Z. A. Imam Supardi ${ }^{3)}$ \\ ${ }^{1)}$ Mahasiswa Program Studi Pendidikan Sains, Program Pascasarjana Universitas Negeri Surabaya \\ ${ }^{2), 3)}$ Dosen Pascasarjana Prodi Pendidikan Sains Universitas Negeri Surabaya \\ E-mail: che_meiazhura@yahoo.com
}

\begin{abstract}
Abstrak: Penelitian ini bertujuan untuk menghasilkan perangkat pembelajaran yang layak untuk meningkatkan hasil belajar siswa sekolah menengah pertama. Pembelajaran ini dilakukan dengan cara menerapkan perangkat pembelajaran model inkuiri terbimbing. Sasaran penelitian adalah perangkat pembelajaran. Penelitian ini merupakan penelitian pengembangan dengan desain perangkat pembelajaran menggunakan model Dick and Carey dan diujicobakan di kelas VIII SMP Negeri 6 Bandar Lampung dengan desain uji coba one group pretest-posttest. Teknik analisis data menggunakan analisis deskriptif kualitatif. Hasil analisis data penelitian menunjukkan bahwa: (1) perangkat pembelajaran yang dikembangkan valid; (2) pembelajaran terlaksana dengan kategori sangat baik; (3) siswa lebih aktif dalam pembelajaran; (4) hasil belajar siswa mengalami peningkatan dengan skor $N$ gain berkategori tinggi; (5) Siswa memberikan respon positif terhadap pembelajaran. Berdasarkan hasil penelitian di atas, dapat disimpulkan bahwa perangkat pembelajaran model inkuiri terbimbing yang telah dikembangkan layak digunakan untuk meningkatkan hasil belajar siswa.
\end{abstract}

Kata kunci: Perangkat Pembelajaran, Model Inkuiri Terbimbing, Hasil Belajar.

Abstract: This study aims to produce a feasible learning materials to improve junior high school learning achievement. Learning takes place by applying the model of guided inquiry learning materials. The research subjectives are learning materials. This research is the development of the design of the learning materials used a model of Dick and Carey and tested in class VIII SMP Negeri 6 Bandar Lampung to the design of the trial one group pretest-posttest. The Data were analyzed using qualitative descriptive analysis. The results showed that: (1) a valid learning materials developed; (2) the learning process took place well; (3) the students were more active in learning; (4) the learning achievement of students has increased by a score of N-gain high category; (5) the students responded positively towards learning. Based on the above results, it can be concluded that the guided inquiry learning model materials that have been developed feasible used to improve student learning achievement.

Keywords: Learning Materials, Guided Inquiry Learning Model, Learning Achievement.

\section{PENDAHULUAN}

Kualitas pendidikan di Indonesia masih di bawah rata-rata negara berkembang lainnya. Hasil survey Trends in International Mathematics and Science Study (TIMSS), kemampuan Indonesia dalam bidang IPA pada tahun 2007 berada pada peringkat 38 dari 40 negara dan pada tahun 2011 turun menjadi peringkat 40 dari 45 negara (Martin, Mullis, \& Foy, 2012). Demikian pula berdasarkan hasil survey Programme for International Student Assessment (PISA) tahun 2012 menunjukkan bahwa kemampuan Indonesia dalam bidang IPA sangat rendah sekali, yaitu peringkat 64 dari 65 negara (OECD, 2014). Hasil yang rendah ini kemungkinan disebabkan karena siswa-siswi di Indonesia terbiasa mengerjakan soal yang hanya menekankan pada penguasaan konsep saja, namun jarang menekankan kemampuan siswa mengidentifikasi masalah, menyelesaikan masalah dengan menerapkan pengetahuan yang telah diperolehnya ke dalam situasi yang baru, berpikir, beragumentasi, membuat keputusan tentang suatu perubahan, serta mengkomunikasikannya.

Berbagai upaya ditempuh oleh pemerintah untuk meningkatkan kualitas pendidikan di Indonesia dengan menyediakan sarana prasarana, penyempurnaan dan pengembangan kurikulum, serta penataran dan pelatihan guru yang dilakukan secara terus menerus. Diberlakukannya kurikulum 2013 dalam dunia pendidikan di Indonesia berimplikasi cukup luas dan kompleks yang berkaitan dengan pembelajaran, pengalaman, dan sistem penilaian. Kurikulum 2013 bertujuan untuk mempersiapkan manusia Indonesia agar memiliki kemampuan hidup sebagai pribadi dan warga negara yang beriman, produktif, kreatif, inovatif, dan afektif, serta mampu berkonstribusi pada kehidupan 
bermasyarakat, berbangsa, bernegara, dan peradapan dunia (Kemendikbud, 2014a). Kurikulum 2013 pada semua jenjang dilaksanakan dengan menggunakan pendekatan saintifik dan mencakup tiga ranah, yaitu sikap, pengetahuan, dan keterampilan. Hal ini sesuai dengan pembelajaran IPA yang meliputi pengetahuan, keterampilan, dan sikap yang diperoleh melalui pengalaman secara langsung.

Menurut National Science Education Standard (NRC, 2000), para siswa perlu untuk mempelajari prinsip- prinsip dan konsep-konsep IPA, mendapatkan keterampilan menalar dan melakukan prosedur kerja ilmuwan sains, serta memahami sifat alami sains sebagai bentuk tertentu dari usaha keras manusia. Jadi, para siswa perlu untuk dapat merancang dan melakukan penyelidikan untuk menguji gagasangagasan mereka dan memahami penyelidikannya.

Berdasarkan observasi, SMP Negeri 6 Bandar Lampung merupakan sekolah yang terletak di dekat pesisir pantai dimana latar belakang pendidikan orang tua rata-rata rendah dan faktor ekonomi orang tua siswa pun redah. Hal ini diduga menyebabkan pola berpikir siswa yang rendah akan pendidikan dimana kegiatan belajar di sekolah hanya sekedar kegiatan rutinitas biasa dan berdasarkan wawancara dari beberapa guru serta data dari guru bimbingan konseling didapatkan bahwa sikap siswa kurang baik seperti tidak jujur, sering menyontek, individual, tidak bertanggung jawab, kurang berkeja sama, kurang sopan santun, sering berkelahi, kepedulian antar sesama yang kurang, dan sebagainya. SMP Negeri 6 bukan termasuk sekolah unggulan di Bandar Lampung dan terkesan tersisihkan karena letaknya di pesisir pantai yang jauh dari pusat kota, meskipun pusat pemerintahan dekat dari sekolah ini.

Permasalahan dalam kegiatan belajar mengajar yang terdapat di SMP 6 Negeri Bandar Lampung diantaranya kegiatan pembelajaran masih berpusat pada guru (teacher centered) dikarenakan kecenderungan model pembelajaran yang digunakan guru masih konvensional yaitu ceramah, dan memberikan latihan soal. Akibatnya siswa menjadi jenuh, bosan, dan kurang berperan serta aktif baik secara fisik maupun mental dalam pembelajaran sehingga hasil belajar siswa rendah.

Model-model pembelajaran yang dianjurkan pada kurikulum 2013 antara lain pembelajaran berbasis penemuan/inkuiri (discovery/inquiry learning), pembelajaran berbasis masalah (problem based learning), dan pembelajaran berbasis proyek (project based learning). Pembelajaran berbasis penemuan/inkuiri (discovery/inquiry learning) perlu diterapkan untuk memperkuat pendekatan ilmiah (Kemendikbud, 2014b). Model pembelajaran inkuiri adalah suatu pembelajaran dimana siswa menemukan dan menggunakan berbagai sumber informasi dan ide- ide tentang masalah atau topik siswa (Kuhltau, 2007). Inkuiri sebagai pendekatan pembelajaran melibatkan penyelidikan dan mengarahkan siswa pada pertanyaan, menguji ide-ide, dan membuat penemuan dalam mencari pemahanan (Ansberry dan Morgan, 2007). Guru harus menggunakan inkuiri untuk mengajarkan IPA dan juga mengajarkan untuk menyelidiki. Guru pun harus memahami tentang penemuan yang akan dibuat dan bagaimana membimbing penyelidikan siswa dengan cara yang baik (Abruscato, 2010).

Pembelajaran inkuiri yang cocok diterapkan pada siswa SMP adalah inkuiri tembimbing (guided inquiry). Piaget menjelaskan bahwa siswa usia 11 tahun dewasa (SMP) berada pada tahap operasi formal dimana masalah-masalah dapat diselesaikan melalui eksperimen, dan dapat menyelesaikan tes dalam kemampuan pemecahan masalah (Slavin, 2006). Hal ini sesuai dengan penelitian yang pernah dilakukan sebelumnya oleh Schwarz \& Gwekwerere (2006), dijelaskan bahwa inkuiri terbimbing dipadukan dengan EIMA (Modeling Instructional Framework) dapat memunculkan ide-ide awal siswa, melibatkan siswa dalam proses pembelajaran, melibatkan siswa dalam mengeksplorasi dan merefleksikan ide-ide mereka. Guru melalui pembelajaran inkuiri terbimbing harus merancang pembelajaran inkuiri yang melibatkan siswa secara aktif dimana pada proses awal pembelajaran guru memberi banyak bimbingan kemudian secara teratur mengurangi frekuensi bimbingan sesuai dengan teori perkembangan sosial Vygotsky yaitu scaffolding. Dengan demikian, siswa dapat menjadi penyelidik yang baik dan pengetahuan ilmiahnya dapat terpenuhi.

Adapun untuk melaksanakan pembelajaran tersebut, untuk membantu dan mempermudah siswa belajar, harus didukung oleh fasilitas yang baik dan perangkat pembelajaran yang baik pula. Perangkat pembelajaran ini meliputi Rencana Pelaksanaan Pembelajaran (RPP), Lembar Kegiatan Siswa (LKS), Buku Ajar Siswa (BAS), dan Instrumen Penilaian. Seorang guru hendaknya dapat membuat perangkat pembelajarannya sendiri. Pembuatan perangkat pembelajaran tersebut tentunya disesuaikan dengan kemampuan siswa, kondisi lingkungan sekolah, dan sesuai tuntutan kurikulum 2013. Adanya perangkat pembelajaran ini diharapkan dapat memaksimalkan hasil belajar siswa. Realitanya, bahan ajar yang ada masih belum disesuaikan dengan kemampuan dan kondisi lingkungan sekolah. Salah satu penyebabnya adalah keterbatasan waktu guru dalam mengembangkan perangkat pembelajaran. LKS yang terdapat di sekolah umumnya berupa buku rangkuman materi pelajaran bersifat teoritis yang disertai kumpulan soal-soal dan tidak menunjukkan aktivitas serta pengalaman belajar siswa secara ilmiah dan bukan dibuat oleh guru, sehingga pembelajaran bukan berpusat pada siswa 
melainkan pada guru dan proses pembelajaran hanya menitikberatkan pada aspek kognitif saja. Dengan demikian, dibutuhkan perangkat pembelajaran yang disusun berdasarkan kaidah metode ilmiah yang diharapkan mampu mengajak siswa berperan aktif dalam pembelajaran dan pengalaman langsung dari proses pembelajaran.

Salah satu materi yang cocok dengan model inkuiri terbimbing, yaitu materi Indera penglihatan dan alat optik dan merupakan materi pelajaran yang berkaitan erat dengan kehidupan sehari-sehari. Materi ini terdapat pada bagian akhir semester genap, tetapi berdasarkan observasi, penyampaian yang dilakukan oleh guru hanya bersifat hafalan dengan mendengarkan penjelasan guru tanpa adanya peran serta aktif siswa. Materi ini sangat memunmgkinkan untuk dijadikan materi yang perlu dikembangkan dengan pembelajaran model inkuiri terbimbing dimana melalui pembelajaran tersebut siswa dapat berperan aktif untuk melakukan penyelidikan dalam menemukan pemahamannya melalui pengalaman langsung dan interaksi terhadap lingkungannya.

Berdasarkan uraian di atas, maka Peneliti bermaksud melakukan penelitian dengan judul "Pengembangan Perangkat Pembelajaran Model Inkuiri Terbimbing untuk Meningkatkan Hasil Belajar Siswa Sekolah Menengah Pertama”.

Permasalahan penelitian ini, yaitu: "Bagaimanakah kelayakan perangkat pembelajaran yang dikembangkan berdasarkan model inkuiri terbimbing untuk meningkatkan hasil belajar siswa sekolah menengah pertama?". Berdasarkan permasalahan penelitian tersbut, maka tujuan dalam penelitian ini adalah untuk mengembangkan perangkat pembelajaran berdasarkan model inkuiri terbimbing yang layak untuk meningktkan hasil belajar siswa sekolah menengah pertama.

Penelitian ini diharapkan agar tersedianya perangkat pembelajaran model inkuiri terbimbing untuk meningkatkan hasil belajar siswa sekolah menengah pertama sebagai masukan bagi guru IPA SMP, memberikan pengalaman belajar bagi siswa untuk melatih siswa belajar mandiri dan terlibat secara aktif dalam pembelajaran, serta sebagai pertimbangan dalam usaha perbaikan proses pembelajaran dan hasil belajar siswa.

\section{METODE PENELITIAN}

Desain penelitian ini merupakan penelitian pengembangan yang dilaksanakan untuk menghasilkan perangkat pembelajaran model inkuiri terbimbing di sekolah menengah pertama. Perangkat yang dikembangkan meliputi: rencana pelaksanaan pembelajaran (RPP), lembar kegiatan siswa (LKS), buku ajar siswa (BAS), dan instrumen penilaian. Desain pengembangan perangkat pembelajaran pada penelitian ini menggunakan model Dick and Carey. Desain penelitian dalam pengembangan perangkat pembelajaran menggunakan model One Group PretestPosttest Design (Tuckman, 1978), yaitu desain yang diterapkan pada suatu kelompok penelitian tanda adanya kelompok pembanding dengan notasi sebagai berikut:

$\begin{array}{lll} & \text { X } & 02\end{array}$

Keterangan :

O1 : Uji awal (pretest), untuk mengetahui pengetahuan awal siswa terhadap materi pembelajaran sebelum diberi perlakuan.

$\mathrm{X}$ : Perlakuan, yaitu penerapan perangkat pembelajaran dengan menggunakan model inkuiri terbimbing (guided inquiry).

O2 : Uji akhir (post-test), untuk mengetahui penguasaan terhadap materi pembelajaran setelah pemberian perangkat pembelajaran dengan menggunakan model inkuiri terbimbing (guided inquiry)

Subjek penelitian pada tahap pengembangan adalah perangkat pembelajaran model inkuiri terbimbing untuk meningkatkan hasil belajar siswa sekolah menengah pertama pada materi indera penglihatan dan alat optik yang diimplementasikan pada siswa kelas VIII SMP Negeri 6 Bandar Lampung.

Teknik pengumpulan data dilakukan dengan menggunakan pengamatan, tes, angket, dan dokumentasi. Instrumen penelitian meliputi, lembar validasi perangkat pembelajaran, lembar pengamatan keterlaksanaan RPP, lembar pengamatan aktivitas siswa, lembar penilaian tes hasil belajar, lembar angket respon siswa, dan lembar pengamatan kendala-kendala pembelajaran. Teknik analisis data menggunakan deskriptif kuantitatif dan kualitatif.

\section{A. Analisis Hasil Validasi Perangkat Pembejaran}

Analisis data validasi perangkat pembelajaran dinalisis secara deskriptif kualitatif, yaitu dengan cara merata-ratakan skor setiap aspek perangkat yang dikembangkan. Hasil penskoran dideskripsikan sebagai berikut:

Tabel 1. Konversi Skala Likert Tingkatan Analisis Validitas Perangkat Pembelajaran

\begin{tabular}{|l|c|l|}
\hline $\begin{array}{c}\text { Interval Nilai } \\
\text { (Skor) }\end{array}$ & $\begin{array}{c}\text { Kategori } \\
\text { Validitas }\end{array}$ & \multicolumn{1}{|c|}{ Keterangan } \\
\hline $1,0 \leq \mathrm{P}<1,6$ & Tidak Valid & Tidak boleh digunakan \\
\hline $1,6 \leq \mathrm{P}<2,2$ & Kurang Valid & Tidak boleh digunakan \\
\hline $2,2 \leq \mathrm{P}<2,8$ & Cukup Valid & $\begin{array}{l}\text { Boleh digunakan } \\
\text { setelah revisi besar }\end{array}$ \\
\hline $2,8 \leq \mathrm{P}<3,4$ & Valid & $\begin{array}{l}\text { Boleh digunakan } \\
\text { setelah revisi kecil }\end{array}$ \\
\hline $3,4 \leq \mathrm{P} \leq 4$ & Sangat Valid & $\begin{array}{l}\text { Sangat baik untuk } \\
\text { digunakan }\end{array}$ \\
\hline
\end{tabular}

(Diadaptasi dari Akbar, 2013) 


\section{B. Analisis Keterlaksanaan RPP}

Analisis data keterlaksanaan RPP yang diperoleh dianalisis dengan analisis deskriptif kualitatif, yaitu dengan cara merata-ratakan setiap aspek yang terlaksana. Kategori nilai keterlaksanaan menggunakan konversi skala Likert lima tingkatan (lima kelas interval). Hasil penskoran dideskripsikan sebagai berikut:

Tabel 2. Konversi Skala Likert Lima Tingkatan Analisis Keterlaksanaan RPP

\begin{tabular}{|c|c|}
\hline Interval Nilai (Skor) & Kategori Keterlaksanaan \\
\hline $1,0 \leq \mathrm{P}<1,6$ & Tidak Baik \\
\hline $1,6 \leq \mathrm{P}<2,2$ & Kurang Baik \\
\hline $2,2 \leq \mathrm{P}<2,8$ & Cukup Baik \\
\hline $2,8 \leq \mathrm{P}<3,4$ & Baik \\
\hline $3,4 \leq \mathrm{P} \leq 4,0$ & Sangat Baik \\
\hline
\end{tabular}

(Diadaptasi dari Akbar,2013)

Persentase keterlaksanaan RPP dirumuskan sebagai berikut:

Keterangan:

P : Persentase Keterlaksanaan RPP

$\sum \mathrm{A}$ : Jumlah aspek yang terlaksana

$\sum \mathrm{N}$ : Jumlah keseluruhan aspek yang diamati

\section{Analisis Aktivitas Siswa}

Analisis aktivitas siswa dalam pembelajaran yang diamati selama kegiatan belajar mengajar dianalisis secara deskriptif kualitatif, yaitu dengan menghitung persentase banyaknya frekuensi tiap aktivitas dibagi dengan seluruh frekuensi aktivitas dikali seratus persen. Persentase aktivitas siswa menggunakan rumus:

$$
P=\frac{\sum A}{\sum N} \times 100 \%
$$

Keterangan:

P : Persentase Aktivitas Siswa

$\sum$ A : Jumlah frekuensi aktivitas yang muncul

$\sum \mathrm{N}$ : Jumlah frekuensi aktivitas

(Adaptasi dari Riduwan, 2008)

\section{Analisis Hasil Belajar}

1. Analisis Data Hasil Belajar Aspek Sikap

Berdasarkan Permendikbud No. 104 Tahun 2014, penilaian sikap diarahkan untuk mengukur pencapaian kompetensi dasar pada sikap spiritual KI-1 dan sikap social KI-2. Nilai ketuntasan kompetensi sikap dituangkan dalam bentuk predikat, yakni predikat Sangat Baik (SB), Baik (B), Cukup (C), dan Kurang (K). Ketuntasan Belajar untuk sikap (KD pada KI-1 dan KI-2) ditetapkan dengan predikat Baik (B). Data hasil belajar aspek sikap diperoleh melalui penilaian dalam lembar pengamatan sikap spiritual dan sosial.

2. Analisis Data Hasil Belajar Aspek Pengetahuan

Analisis data hasil belajar aspek pengetahuan dianalisis untuk menentukan pencapaian tujuan pembelajaran. Berdasarkan hasil pretest dan posttest kemudian dinalisis secara deskriptif kuantitatif yang terdiri dari:

a) Ketuntasan Indikator/Tujuan Pembelajaran

Analisis yang digunakan untuk menganalisis ketuntasan indikator hasil belajar tiap siswa adalah deskriptif kuantitatif. Suatu indikator dikatakan tuntas apabila persentase (P) siswa mencapai indikator tersebut $\geq 75 \%$. Rumusan persentase $(\mathrm{P})$ ketuntasan indikator dapat dihitung dengan cara sebagai berikut:

$P_{\text {indikator }}=\frac{\text { jumlah siswn ynomg monropni imdiknt or tar sohut. }}{\text { jumlah soluruh siswo }} \times 100 \%$

b) Ketuntasan Individu dan Klasikal

Berdasarkan Permendikbud No. 104 Tahun 2014, ketuntasan belajar untuk pengetahuan tercapai bila skor minimalnya mencapai 2,67. Nilai siswa secara individu adalah jumlah skor yang diperoleh siswa dibagi skor maksimal kemudian dikalikan 100 , seperti rumus berikut: dikalikan 100, seperti rumus berikut:

Nilai $=\frac{\text { Jumlah skoryangdiperoleh siswa }}{\text { Skur Muksimul }} \times 100$

(Kemendikbud, 2014c)

Selanjutnya, nilai siswa yang diperoleh dikonversi sesuai pedoman penilaian Kurikulum 2013, seperti dibawah ini:

$$
\text { Skor }=\begin{gathered}
\text { NiLal } \\
100
\end{gathered} \times 4
$$

Sedangkan kentuntasan secara klasikal adalah jumlah siswa yang tuntas dibagi dengan jumlah seluruh siswa dikalikan 100 atau dapat dirumuskan sebagai berikut:

$$
P_{\text {Klasihal }}=\frac{\text { jumlah siswa yang tuntas }}{\text { jumlah seluruh siswa }} \times 100 \%
$$

c) Sensitivitas Butir Soal

Sensitivitas butir soal digunakan untuk mengetahui sejauh mana tiap butir soal mampu mengukur efek pembelajaran. Sensitivitas butir soal dihitung dnegan menggunakan rumus sebagai berikut:

$$
S=\frac{R_{A}-R_{B}}{T}
$$

Keterangan:

$$
\begin{aligned}
& \mathrm{S} \text { : Indeks sensitivitas soal } \\
& \mathrm{T} \text { : banyak siswa yang mengikuti tes } \\
& \mathrm{Ra}: \text { Jumlah siswa yang menjawab benar pada } \\
& \text { tes akhir } \\
& \mathrm{Rb} \text { : Jumlah siswa yang menjawab benar pada } \\
& \quad \text { tes awal }
\end{aligned}
$$

(Gronlund, 1977)

Sedangkan untuk mengetahui indeks sensitivitas butir soal bentuk soal uraian menggunakan rumus: 


$$
S=\frac{\sum U_{12}-\sum U_{21}}{N(\text { Sicor } \max -\text { Skor min })}
$$

Keterangan:

$$
\mathrm{S} \quad \text { : Indeks sensitivitas soal }
$$

$\sum \mathrm{U} 12$ : Jumlah skor posttest (sebelum pembelajaran berlangsung)

$\sum \mathrm{U} 21$ : Jumlah skor pretest (setelah pembelajaran berlangsung)

Skor max: Skor maksimal yang dicapai untuk setiap butir tes

Skor min: Skor minimal yang dicapai untuk setiap butir tes

$\mathrm{N} \quad$ : Jumlah siswa yaang mengikuti tes

(Sa’diyah, 2014)

Nilai sensitivitas berada pada $0,00-1,00$, dimana sensitivitas 0,00 berarti tidak sensitif sedangkan 1,00 berarti sangat sensitif.

\section{d) Perhitungan Gain Skor}

Gain skor menunjukkan perbedaan hasil belajar siswa sebelum dan sesudah perlakuan. Persamaan untuk menghitung $N$-Gain sebagai berikut:

$(g)=\begin{aligned} & s_{\text {post }}-s_{\text {pre }} \\ & S_{\text {max }}-s_{\text {pro }}\end{aligned}$

Keterangan:

$$
\begin{aligned}
& <\mathrm{g}>\quad \text { : Nilai Gain } \\
& \text { Spre }: \text { Nilai pretest } \\
& \text { Spost : Nilai posttest } \\
& \text { Smax : Nilai maksimal }
\end{aligned}
$$

(Diadaptasi dari Hake, 1999)

Nilai $<\mathrm{g}>$ yang diperoleh dikonversi dengan kategori Normalized Gain sebagai berikut:

Tabel 3. Kategori Normalized Gain

\begin{tabular}{|c|c|}
\hline Nilai Gain & Kategori \\
\hline $0,70<<\mathrm{g}>$ & Tinggi \\
\hline $0,30 \leq<\mathrm{g}>\leq 0,70$ & Sedang \\
\hline$<\mathrm{g}><0,30$ & Rendah \\
\hline
\end{tabular}

(Diadaptasi dari Hake, 1999)

3. Analisis Data Hasil Belajar Aspek Keterampilan

Data hasil Analisis aspek keterampilan diperoleh melalui pengamatan pada saat siswa mengikuti kegiatan pembelajaran dengan menggunakan lembar observasi. Berdasarkan Permendikbud No. 104 Tahun 2014, ketuntasan belajar untuk keterampilan ditetapkan dengan capaian optimum 2,67. Nilai keterampilan dihitung dengan menggunakan persamaan sebagai berikut: menggunakan persamaan sebagai berikut:

Nilal $=\frac{\text { Iumlah skor yang diperoleh siswa }}{\text { a }} \times 100$

(Kemendikbud, 2014d)

Selanjutnya, nilai siswa yang diperoleh dikonversi sesuai pedoman penilaian Kurikulum 2013, seperti dibawah ini: $\quad$ skor $=\frac{\text { Nilai }}{100} \times 4$

\section{E. Analisis Respon Siswa}

Respon siswa diperoleh dari angket respon siswa terhadap kegiatan pembelajaran yang selanjutnya dinalisis secara deskriptif kuantitatif, yaitu dengan menghitung persentase terhadap pernyataan yang diberikan. Persentase respon siswa dihitung dengan menggunakan rumus:

$P=\frac{\sum R}{\sum N} \times 100 \%$

Keterangan:

P : Persentase Keterlaksanaan RPP

$\sum \mathrm{R}$ : Jumlah frekuensi respon siswa yang teramati

$\sum \mathrm{N}$ : Jumlah frekuensi seluruh kategori respon

(Riduwan, 2008)

\section{HASIL PENELITIAN DAN DISKUSI}

\section{A. Validitas Perangkat Pembelajaran}

Hasil validasi perangkat pembelajaran digunakan sebagai dasar untuk membahas validitas perangkat pembelajaran yang telah dikembangkan dimana perangkat pembelajaran tersebut telah divalidasi oleh dua orang velidator ahli. Hasil validasi perangkat pembelajaran secara ringkas disajikan pada Tabel 4.

Tabel 4. Hasil Validitas Perangkat Pembelajaran

\begin{tabular}{|c|l|c|c|c|}
\hline \multirow{2}{*}{ No } & \multirow{2}{*}{ Jenis Perangkat } & \multicolumn{2}{|c|}{ Validitas } & \multicolumn{2}{|c|}{$\begin{array}{c}\text { Rerata } \\
\text { Skor }\end{array}$} & Kategori & Reliabilitas \\
\hline 1 & RPP & 3,68 & $\begin{array}{c}\text { Sangat } \\
\text { Valid }\end{array}$ & $97,86 \%$ \\
\hline 2 & LKS & 3,76 & $\begin{array}{c}\text { Sangat } \\
\text { Valid }\end{array}$ & $96,64 \%$ \\
\hline 3 & BAS & 3,70 & $\begin{array}{c}\text { Sangat } \\
\text { Valid }\end{array}$ & $98,55 \%$ \\
\hline 4 & $\begin{array}{l}\text { Instrumen } \\
\text { penilaian aspek } \\
\text { sikap }\end{array}$ & 3,70 & $\begin{array}{c}\text { Sangat } \\
\text { Valid }\end{array}$ & $98,55 \%$ \\
\hline 5 & $\begin{array}{l}\text { Instrumen } \\
\text { penilaian aspek } \\
\text { pengetahuan }\end{array}$ & 3,58 & $\begin{array}{c}\text { Sangat } \\
\text { Valid }\end{array}$ & $97,62 \%$ \\
\hline 6 & $\begin{array}{l}\text { Instrumen } \\
\text { penilaian aspek } \\
\text { keterampilan }\end{array}$ & 3,66 & Sangat \\
Valid & $96,36 \%$ \\
\hline
\end{tabular}

Berdasarkan Tabel 4 di atas dapat dimaknai bahwa perangkat pembelajaran yang terdiri dari RPP, LKS, BAS, dan instrumen penilaian dapat dikategorikan sangat valid (Akbar, 2013). Reabilitas validasi perangkat pembelajaran yang dikembangkan dikategorikan reliabel untuk digunakan oleh guru dalam pembelajaran (Borich dalam Ibrahim, 2005).

Rencana Pelaksanaan Pembelajaran (RPP) yang dikembangkan mengacu pada format kurikulum 2013. RPP dibuat dalam empat kali pertemuan dengan alokasi waktu 3 x 40 menit (pertemuan ke-1 dan ke-3) dan 2 x 40 menit (pertemuan ke-2 dan ke-4). Alokasi waktu tersebut disesuaikan dengan Permendikbud No. 58 tentang Kurikulum 2013 pada jenjang SMP/MTs yang mengatur jumlah jam pelajaran IPA SMP/MTs 
adalah 5 x 40 menit per minggu (Kemendikbud, 2014a). Kegiatan pembelajaran yang terdapat dalam RPP disesuaikan dengan langkah-langkah model pembelajaran inkuri terbimbing dan pendekatan saintifik.

Lembar Kegiatan Siswa (LKS) yang dikembangkan, disesuaikan dengan pembelajaran model inkuiri terbimbing dan pendekatan saintifik pada RPP yang dikembangkan. Bentuk LKS yang dikembangkan berupa LKS eksperimen dan LKS non ekperimen model reconstruction DART, yaitu text completion dan diagram completion (Devi, 2009). LKS yang disusun pada penelitian ini sebanyak empat buat untuk empat kali pertemuan. LKS yang dikembangkan di dalamnya memuat sejumlah pertanyaan-pertanyaan yang ditujukan untuk membantu siswa mencapai kompetensi yang diinginkan dan disediakan tempat jawaban siswa untuk memudahkan siswa menuliskan jawabannya. Menurut Astuti \& Setiawan (2013) bahwa banyaknya pertanyaan dalam LKS bertujuan agar siswa bekerja dalam kelompok secara maksimal.

Buku Ajar Siswa (BAS) yang telah dikembangkan merupakan buku panduan belajar yang digunakan baik dalam proses kegiatan pembelajaran di kelas maupun belajar mandiri. Isi buku disesuaikan dengan kompetensi dasar indikator pembelajaran, dan tujuan pembelajaran pada kurikulum 2013. Adapun kedalaman atau keluasan materi, kesesuaian uraian konsep yang dilengkapi contoh penerapan dalam kehidupan seharihari, menyajikan situs website pembelajaran yang dapat diakses secara online untuk mendapatkan lebih banyak informasi, serta dukungan tampilan gambar yang menarik.

Instrumen penilaian sikap digunakan untuk merekam data sikap siswa selama kegiatan pembelajaran berlangsung. Sikap siswa yang diamati menyangkut sikap spiritual, sikap jujur, dan sikap menghargai. Adapun indikator dari sikap spiritual, yaitu (a) mensyukuri keteraturan sifat cahaya dan kompleksitas pembentukan bayangan pada pemantulan dan pembiasan cahaya sebagai ciptaan Tuhan yang sempurna dan (b) mensyukuri keteraturan dan kompleksitas susunan, struktur, dan fungsi bagianbagian mata sebagai indera penglihatan manusia yang telah diciptakan Tuhan. Indikator sikap jujur, yaitu (a) tidak menyontek hasil penyelidikan siswa lain dan atau saat pretest-posttest, dan (b) membuat laporan berdasarkan data yang didapatkan. Indikator sikap menghargai, yaitu (a) memberi kesempatan kepada teman atau kelompok lain untuk mengemukakan pendapat dan (b) tidak mencela orang lain atau kelompok lain yang memberikan pendapat. Instrumen penilaian ini disusun berdasarkan Pemendikbud No. 104 Tahun 2014. Instrumen penilaian sikap ini tidak untuk menentukan skor aspek siswa, akan teramati untuk mengamati frekuensi sikap siswa yang teramati atau muncul selama proses pembelajaran berlangsung.

Selanjutnya, butir soal tes aspek pengetahuan yang dikembangkan sebanyak 26 butir soal dengan rincian 11 soal pilihan ganda dan 15 soal esai. Butir soal yang dikembangkan dikategorikan layak dan memenuhi syarat untuk digunakan dalam pembelajaran dimana penyusunan telah mengacu pada indikator dan tujuan pembelajaran yang telah dikembangkan, berdasarkan pada Permendikbud No. 104 Tahun 2014, dan juga berpedoman pada aspek pengetahuan taksonomi Bloom Revisi.

Instrumen penilaian aspek keterampilan adalah instrumen yang dipakai untuk mengamati siswa dalam menuliskan laporan hasil penyelidikan meliputi, (1) Menuliskan judul laporan dan nama anggota kelompok, (2) menuliskan tujuan penyelidikan, (3) menuliskan alat dan bahan yang telah digunakan, (4) menuliskan prosedur penyelidikan, (5) menuliskan data hasil penyelidikan, (6) menganalisis data yang diperoleh, (7) menyimpulkan hasil penyelidikan, dan (8) menuliskan sumber referensi. Instrumen penilaian yang dikembangkan dilengkapi dengan rubrik penilaian untuk memudahkan pelaksanaan penilaian.

\section{B. Keterlaksanaan RPP}

Rata-rata skor keterlaksanaan RPP sebesar 3,72 dengan kategori sangat baik dan rata-rata persentase nilai keterlaksanaan $92,50 \%$ berkategori sangat baik (Akbar, 2013). Hal ini menunjukkan bahwa pembelajaran dengan menggunakan model inkuiri terbimbing dapat terlaksana sesuai denngan rencana pembelajaran yang telah dikembangkan. Pembelajaran pada awal pertemuan belum berjalan sesuai dengan yang direncanakan dikarenakan siswa yang masih belum terbiasa dengan model pembelajaran yang diterapkan, sehingga pada awal pertemuan guru banyak melakkukan bimbingan kepada siswa. Namun, bimbingan kepada siswa dikurangi sedikit demi sedikit pada pertemuan selanjutnya dan akhirnya siswa dapat mandiri. Hal ini sesuai dengan proses scaffolding dari Vigotsky (Slavin, 2006). Pembelajaran inkuri terbimbing (guided inquiry) adalah zona intervensi (campur tangan) dimana petunjuk dan bantuan khusus diberikan untuk membimbing siswa dalam mengumpulkan informasi untuk menyelesaikan tugasnya kemudian sedikit demi sedikit dikurangi sesuai dengan perkembangan pengalaman siswa (Kuhlthau, 2007).

\section{Aktivitas Siswa}

Aktivitas siswa yang diamati dalam pembelajaran, meliputi: (1) mendengarkan/memperhatikan penjelasan guru; (2) menjawab pertanyaan guru; (3) mengerjakan 
LKS; (4) mengamati yang disajikan guru; (5) mengajukan pertanyaan; (6) membaca dan mencermati petunjuk LKS; (7) merencanakan penyelidikan; (8) melaksanakan penyelidikan; (9) mengumpulkan dan menganalisis data; (10) membuat kesimpulan hasil penyelidikan; (11) membuat laporan hasil penyelidikan; (12) mempresentasikan hasil penyelidikan; (13) menjawab dan menanggapi penyajian kelompok lain; (14) menyampaikan pendapat; (15) menyimpulkan hasil pembelajaran; (16) tindakan yang tidak relevan.

Aktivitas siswa dalam kegiatan pembelajaran telah mencerminkan aktivitas yang sesuai dengan tahaptahap pembelajaran model Pertemuanin 4 inkuiri terbimbing. Persentase frekuensi aktivitas siswa yang paling dominan dilakukan siswa adalah mengamati yang disajikan guru (10,52\%), mengajukan pertanyaan $(10,00 \%)$, membuat laporan hasil penyelidikan $(9,27 \%)$, serta mengumpulkan dan menganalisis data $(9,21 \%)$. Hal ini menunjukkan bahwa penggunaan pembelajaran model inkuiri terbimbing merupakan pembelajaran berpusat pada siswa yang membuat siswa lebih aktif dalam kegiatan pengamatan, mengajukan pertanyaan, mencari mencari rujukan atas data yang diperoleh melalui buku- buku dan sumber informasi lainnya, merencanakan penyelidikan, meninjau ulang apa yang diketahui dari bukti-bukti hasil percobaan sederhana, menggunakan perangkatperangkat untuk mengumpulkan, menganalisis dan menginterpretasi data, pengajuan jawaban, penjelasan dan perkiraan, serta mengkomunikasikan hasil (NRC, 2000). Belajar menjadi bermakna bagi siswa apabila meraka mendapat kesempatan untuk mengajukan pertanyaan, melaksanakan penyelidikan, menggumpulkan data, membuat kesimpulan, dan berdiskusi (Rustaman, 2005).

Bruner menegaskan bahwa orang dapat belajar dengan baik ketika mereka secara aktif terlibat daripada menjadi penerima pasif informasi (Kuhlthau, 2007). Hal ini didukung oleh penelitian Agustanti (2012) bahwa pembelajaran inkuiri dapat menjadikan siswa aktif, bergairah, antusias, berpartisipasi dalam pembelajaran.

\section{Hasil Belajar Siswa}

1. Aspek Sikap

Hasil belajar aspek sikap siswa diperoleh melalui data hasil pengamatan terhadap sikap yang muncul pada siswa selama kegiatan pembelajaran berlangsung. Sikap yang diamati meliputi sikap spiritual, sikap jujur, dan sikap menghargai. Adapun indikator dari sikap (1) spiritual, yaitu (a) mensyukuri keteraturan sifat cahaya dan kompleksitas pembentukan bayangan pada pemantulan dan pembiasan cahaya sebagai ciptaan Tuhan yang sempurna dan (b) mensyukuri keteraturan dan kompleksitas susunan, struktur, dan fungsi bagian- bagian mata sebagai indera penglihatan manusia yang telah diciptakan Tuhan. Indikator sikap (2) jujur, yaitu (a) tidak menyontek hasil penyelidikan siswa lain dan atau saat pretest-posttest, dan (b) membuat laporan berdasarkan data atau informasi sesuai dengan hasil yang didapatkan. Indikator sikap (3) menghargai, yaitu (a) memberi kesempatan kepada teman atau kelompok lain untuk mengemukakan pendapat dan (b) tidak mencela orang lain atau kelompok lain yang memberikan pendapat.

n 3 Indikator 1-b dan 3-b dilakukan oleh siswa dengan persentase $100 \%$, indikator 1 -a dilakukan siswa dengan persentase $95,00 \%$, indikator 2-b dilakukan siswa $76,00 \%$, dan indikator 3-a dilakukan siswa dengan persentase $92 \%$. Hal ini menunjukkan bahwa proses pembelajaran yang telah dilaksanakan dapat memperkuat rasa syukur siswa, membuat laporan sesuai dengan data atau informasi yang didapatkan, serta menghargai teman atau kelompok lain. Siswa bekerja sama dalam kelompoknya dengan berdiskusi untuk mencari dan menemukan jawaban sendiri dari sesuatu yang dipertanyakan saat melakukan kegiatan penyelidikan. Ada banyak keuntungan dalam diskusi kelompok, antara lain siswa terlibat langsung dan memiliki kesempatan untuk berpastisipasi, membantu siswa belajar mengekspresikan dirinya sendiri, menyampaikan pendapat, dan toleransi terhadap pandangan-pandangan yang berbeda (Woolfolk, 2009). Maka dari itu, siswa harus dapat menghargai pendapat teman maupun kelompok lain dengan memberi kesempatan untuk menyampaikan pendapat dan tidak mencela saat orang lain atau kelompok lain menyampaikan pendapatnya. Berdasarkan penelitian yang telah dilakukan oleh Natalina, dkk (2013), siswa memiliki cara pandang yang berbeda melihat suatu permasalahan dan cara pandang yang berbeda membuat siswa memiliki pendapat yang berbeda sehingga dalam banyaknya perbedaan siswa mampu menunjukkan sikap menghargai pendapat maupun jawaban yang berbeda.

Indikator 2-a adalah indikator yang paling sedikit dilakukan oleh siswa dengan persentase $67,00 \%$. Hal ini terjadi karena di awal pertemuan saat sebagian siswa masih belum dapat berperilaku jujur saat pretest dan atau menyontek hasil penyelidikan siswa lain dimana hal ini sudah menjadi kebiasaan yang sering dilakukan oleh siswa tersebut. Namun, setelah adanya perbaikan dan perlakukan pada pertemuan selanjutnya perilaku ini sedikit demi sedikit berkurang dan siswa dapat berperilaku jujur serta percaya diri dengan hasil yang didapatkannya.

\section{Aspek Pengetahuan}

Berdasarkan hasil penelitian, diketahui bahwa presentase ketuntasan siswa pada saat pretest sebesar $0 \%$ yang artinya semua siswa belum mencapai 
ketuntasan dengan rata-rata skor yang diperoleh 1,12 atau dengan predikat $\mathrm{D}+$. Hal ini terjadi dikarenakan siswa belum mengikuti pembelajaran pada materi indera penglihatan dan alat optik sebelumnya, sehingga jawaban mereka saat pretest hanya berdasarkan pengetahuan awal atau bahkan perkiraan siswa sedangkan hasil postest berbanding terbalik dengan hasil pretest dengan persentase ketuntasan siswa sebesar $100 \%$ dengan rata-rata skor yang diperoleh 3,63 atau dengan predikat A-. Berdasarkan Permendikbud No. 104 Tahun 2014, siswa dikatakan tuntas untuk aspek pengetahuan bila skor minimalnya mencapai 2,67. Ketuntasan belajar ini sangat berkaitan dengan keaktifan siswa untuk terlibat dalam pembelajaran yang berpusat pada siswa. Hal ini menandakan bahwa pembelajaran dengan model inkuiri terbimbing dapat meningkatkan hasil belajar aspek pengetahuan. Berdasarkan penelitian Sa'diyah (2014) yang menyimpulkan bahwa pendekatan inkuiri terbimbing (guided inquiry) dapat meningkatkan hasil belajar siswa, begitu pun dengan penelitian Yunus, dkk (2013) dan Banerjee yang menyimpulkan bahwa siswa memiliki sikap lebih positif terhadap pembelajaran berbasis inkuiri terbimbinng (guided inquiry) dan dapat meningkatkan hasil belajar siswa serta membantu siswa meningkatkan rasa percaya diri. Data ketuntasan pretest dan posttest yang telah dipaparkan di atas menunjukkan adanya peningkatan pemahaman dan pengetahuan siswa tentang materi indera penglihatan dan alat optik.

Peningkatan tersebut dapat diketahui juga melalui hasil peroleh skor rata-rata $\mathrm{N}$-gain yaitu sebesar 0,76 dengan kategori tinggi (Hake, 1999). Tes hasil belajar aspek pengetahuan dikatakan baik atau tidak, maka digunakan analisis sensitivitas butir soal. Sensitivitas butir soal yang telah dianalisi menunjukkan perolehan skor dengan rentang 0,31-0,70 dengan kategori sensitif (Gronlund, 1977). Hasil yang diperoleh tersebut menunjukkan bahwa tiap butir soal yang telah dikembangkan memiliki kepekaan yang cukup terhadap efek pembelajaran yang diberikan. Hal ini menunjukkan bahwa peningkatan hasil belajar siswa merupakan efek dari pelaksanaan pembelajaran dengan menggunakan perangkat pembelajaran model inkuiri terbimbing yang telah dikembangkan.

3. Aspek Keterampilan

Hasil belajar aspek keterampilan siswa diperoleh melalui pengamatan selama kegiatan pembelajaran dalam empat kali pertemuan pada saat siswa menuliskan laporan hasil penyelidikan. Aspek yang dinilai antara lain: (1) menuliskan judul laporan dan nama anggota kelompok; (2) menuliskan tujuan penyelidikan; (3) menuliskan alat dan bahan yang telah digunakan; (4) menuliskan prosedur penyelidikan; (5) menuliskan data hasil penyelidikan; (6) menganalisis data yang diperoleh; (7) menyimpulkan hasil penyelidikan; dan (8) menuliskan sumber referensi. Hasil analisis menunjukkan bahwa seluruh siswa dinyatakan tuntas dengan skor antara 3,67 - 4,00 dengan predikat A- dan A. Rata-rata skor optimum terendah dari aspek yang nilai, yaitu aspek nomor 8 sebesar 3,25. Skor optimum adalah skor maksimal yang dihasilkan oleh siswa selama empat kali pertemuan. Berdasarkan Permendikbud No. 104 Tahun 2014, siswa dikatakan tuntas untuk aspek keterampilan ditetapkan dengan capaian optimum 2,67.

Keterampilan menuliskan laporan hasil penyelidikan bagi siswa adalah suatu hal yang baru, sehingga pada pertemuan pertama banyak siswa mengalami kesulitan serta memerlukan waktu yang lebih untuk membimbing siswa dalam menuliskan laporan hail penyelidikan yang benar. Setelah dilakukan bimbingan dan perbaikan pada pertemuan selanjutnya hasil yang didapatkan lebih baik. Siswa mengalami kesulitan yang paling banyak dalam menuliskan sumber referensi atau daftar pustaka hingga pada pertemuan keempat pun masih ada siswa yang belum benar menuliskan sumber referensi.

\section{E. Respon Siswa}

Rata-rata keseluruhan hasil analisis respon siswa sebanyak $97,27 \%$ siswa memberikan respon positif dan sebanyak 2,73\% memberikan respon negatif. Hasil rekapitulasi dari respon siswa dapat dilihat pada Tabel 5 berikut.

Tabel 5. Hasil Analisis Data Respon Siswa

\begin{tabular}{|l|l|l|}
\hline No. & \multicolumn{1}{|c|}{ Uraian } & \multicolumn{1}{|c|}{ Respon Siswa } \\
\hline 1 & Rata-rata respon siswa & $97,62 \%$ tertarik, \\
& terhadap komponen & $2,38 \%$ tidak \\
& perangkat pembelajaran & tertarik \\
\hline 2 & Rata-rata respon siswa & $93,14 \%$ hal baru, \\
& terhadap penerapan & $6,86 \%$ hal \\
& perangkat pembelajaran & tidak baru \\
\hline 3 & Rata-rata respon & $96,80 \%$ menarik, \\
& ketertarikan siswa & $3,20 \%$ \\
& terhadap buku/ materi ajar & tidak \\
\hline 4 & Rata-rata respon & $98,80 \%$ menarik, \\
& ketertarikan siswa & $1,20 \%$ \\
& terhadap LKS & tidak \\
\hline 5 & Rata-rata minat siswa & $100 \%$ berminat, \\
& untuk mengikuti kegiatan & $0 \%$ \\
& pembelajaran dengan & tidak berminat \\
& model inkuiri terbimbing & \\
& untuk topik-topik & \\
& selanjutnya & \\
\hline
\end{tabular}

\section{F. Kendala-kendala Pembelajaran}

Beberapa kendala pembelajaran yang muncul selama kegiatan pembelajaran, yaitu (1) pembelajaran model inkuiri terbimbing merupakan hal yang baru bagi siswa, sehingga siswa belum terbiasa dan guru mengalami kesulitan dalam menerapkan pembelajaran ini; (2) pembelajaran model inkuiri terbimbing 
memerlukan waktu yang lama karena siswa harus berperan aktif secara mandiri; (3) siswa belum terbiasa dalam menuliskan laporan hasil penyelidikan; dan (4) pengamatan aspek sikap spiritual siswa sangat sulit dikarenakan jumlah siswa yang banyak dibandingkan dengan jumlah pengamat dan indikator ketercapaian sikap spiritual siswa yang kurang begitu jelas.

Hal yang dilakukan guru untuk mengatasi kendalakendala tersebut diantaranya: (1) memperkenalkan pembelajaran model inkuiri terbimbing dan melakukan pendekatan serta penjelasan terhadap langkah-langkah pembelajaran model inkuiri terbimbing; (2) mengingatkan siswa agar tepat waktu dan menggunakan waktu seefektif mungkin; (3) memberikan arahan dan bimbingan terhadap langkahlangkah dalam menuliskan laporan hhasil penyelidikan; dan (4) mencari alternatif instrumen penilaian sikap spiritual siswa lainnya yang dapat menunjang ketercapaian sikap spiritual siswa.

\section{G. Temuan Penelitian}

Berdasarkan hasil analisis dan pembahasan hasil penelitian pengembangan perangkat dan penerapan pembelajaran model inkuiri terbimbing untuk meningkatkan hasil belajar siswa sekolah menengah pertama, diperoleh temuan sebagai berikut:

1. Perangkat pembelajaran dengan model inkuiri terbimbing untuk meningkatkan hasil belajar siswa yang telah dikembangkan dinyatakan valid dan dapat digunakan dalam kegiatan pembelajaran.

2. Keterlaksanaan RPP selama proses pembelajaran dengan rata-rata keseluruhan skor keterlaksanaannya dikategorikan sangat baik.

3. Hasil pengamatan aktivitas siswa pada hasil penelitian diketahui bahwa persentase aktivitas yang paling dominan selama empat kali pertemuan adalah mengamati yang disajikan guru, mengajukan pertanyaan, membuat laporan hasil penyelidikan, serta mengumpulkan dan menganalisis data.

4. Penerapkan perangkat pembelajaran model inkuiri terbimbing dapat mengembangkan aspek sikap siswa. Hasil belajar aspek sikap spiritual dan sikap sosial dilakukan siswa dengan baik.

5. Penerapkan perangkat pembelajaran model inkuiri terbimbing dapat meningkatkan hasil belajar siswa aspek pengetahuan. Peningkatan hasil belajar aspek pengetahuan dapat dilihat dari $N$-gain, yaitu 0,76 dengan kategori tinggi.

6. Penerapkan perangkat pembelajaran model inkuiri terbimbing dapat mengembangkan aspek keterampilan siswa. Hasil belajar siswa aspek keterampilan dinyatakan tuntas dengan ratarata skor 3,85 berpredikat A-.
7. Pembelajaran model inkuiri terbimbing memberikan respon positif dengan persentase $97,27 \%$ siswa yang memberikan respon positif

\section{KESIMPULAN}

\section{A. Simpulan}

Berdasarkan hasil penelitian dan pembahasan, maka dapat disimpulkan bahwa perangkat pembelajaran model inkuiri terbimbing yang dikembangkan layak digunakan untuk meningkatkan hasil belajar siswa sekolah menengah pertama..

\section{B. Saran}

Berdasarkan hasil penelitian, saran yang dapat diajukan adalah sebagai berikut:

1. Pembelajaran dengan model inkuiri terbimbing sebaiknya dipersiapan dan dikelola pengaturan waktunya dengan efektif dan efesien, sehingga pembelajaran dapat berjalan dengan baik.

2. Guru hendaknya melakukan pendekatan dan bimbingan yang lebih banyak kepada siswa dalam penerapan pembelajaran model inkuiri terbimbing, sehingga guru tidak terlalu sulit dalam menerapkan model pembelajaran ini dan dalam menuliskan laporan hasil penyelidikan agar siswa tidak kesulitan menuliskan laporan hasil penyelidikan.

3. Peran guru selain sebagai fasilitator, diharapkan juga sebagai motivator sehingga guru dapat terus memberikan motivasi kepada siswa agar siswa dapat berperan aktif dalam pembelajaran.

4. Guru sebaiknya mencari alternatif insrumen penilaian sikap spiritual lainnya selain dengan cara observasi sehingga memudahkan guru dalam menilai ketercapaian aspek sikap spiritual siswa.

\section{REFERENSI}

Abruscato, J. \& DeRosa, D.A. (2010). Teaching Children Science: Discovery Methods for Elementary and Middle Grades. Boston: Pearson Education, Inc.

Agustanti, T.H. (2012). Implementasi Metode Inquiry Untuk Meningkatkan Hasil Belajar Biologi. Jurnal Pendidikan IPA Indonesia. JPII Vol. 1 No. 1, pp, 19-20.

Akbar, S. (2013). Instrumen Perangkat Pembelajaran. Bandung: Remaja Rosdakarya.

Ansberry, K. \& Morgan, E. (2007). More PicturePerfect Science Lessons: Using Children's Books to Guide Inquiry. Virginia: NSTA Press.

Astuti, Y. \& Setiawan, B. (2013). Pengembangan Lembar Kerja Siswa (LKS) Berbasis Pendekatan Inkuiri Terbimbing dalam Pembelajaran Kooperatif Pada Materi Kalor. Jurnal Pendidikan IPA Indonesia. 2 (1) (2013) 88-92.

Devi, K.P., Sofiraeni, R., dan Khairuddin. 
(2009). Pengembangan Perangkat Pembelajaran. Bandung: PPPPTK IPA.

Gronlund, N.E. (1977). Constructing Achievement Test 2nd Edition. USA: Prentice-Hall, Inc.

Hake, R.R. (1999). Analyzing Change/Gain Scores. http://www.physics.indiana.edu/ $\sim$ sdi/Analyzing Chang e-Gain.pdf. Diakses 25 Februari 2015.

Ibrahim, M. (2005). Asesmen Berkelanjutan. Surabaya: Unesa University Press.

Kemendikbud. (2014a). Lampiran I Peraturan Menteri Pendidikan dan Kebudayaan Republik Indonesia Nomor 58 Tahun 2014 Tentang Kurikulum 2013 Sekolah Menengah Pertama/Madrasah Tsanawiyah. Jakarta: Depdikbud.

Kemendikbud. (2014b). Lampiran III Peraturan Menteri Pendidikan dan Kebudayaan Republik Indonesia Nomor 58 Tahun 2014 Tentang Kurikulum 2013 Sekolah Menengah Pertama/Madrasah Tsanawiyah: PMP IPA SMP. Jakarta: Depdikbud.

Kemendikbud. (2014c). Lampiran Peraturan Menteri Pendidikan dan Kebudayaan Republik Indonesia Nomor 103 Tahun 2014 Tentang Pembelajaran Pada Pendidikan Dasar dan Pendidikan Menengah. Jakarta: Depdikbud.

Kemendikbud. (2014d). Panduan Penilaian Pencapaian Kompetensi Peserta Didik Sekolah Menengah Pertama. Jakarta: Depdikbud

Kuhlthau, C.C., Manioties, L.K., \& Caspari, A.K. (2007). Guided Inquiry: Learning in the 21 London: Libraries Unlimited.

Martin, M.O., Mullis, I.V.S., Foy P., \& Stanco G.M. (2012). TIMSS 2011 International Results in Science. USA: TIMMS \& PIRLS International Study Center.

Natalina, M., Mahadi, I, dan Suzane A.C. (2013). Penerapan Model Pembelajaran Inkuiri Terbimbing (Guided Inquiry) untuk Meningkatkan sikap Ilmiah dan Hasil Belajar Biologi Siswa Kelas XI IPA5 SMA Negeri 5 Pekanbaru Tahun Ajaran 2011/2012. Prosiding Semirata FMIPA Universitas Lampung 2013.
Hal 83-92.

National Research Council. (2000). Inquiry and The National Science education Standards, A Guide for Teaching and Learning (Penerjemah SEAMEO QITEP in Science). Bandung: SEAMEO QITEP in Science.

OECD. (2014). PISA 2012 Results in Focus: What 15year-olds know and what they can do with what they

know. http://www.oecd.org/pisa/keyfindings/pisa2012-results-overview.pdf. Diakses 7 Oktober 2014.

Riduwan. (2008). Skala Pengukuran Variabelvariabel Penelitian. Bandung: Alfabeta.

Rustaman, N. Y. (2005). "Perkembangan Penelitian Pembelajaran Inkuiri dalam Pendidikan Sains". Makalah dipresentasikan dalam Seminar Nasional II. Bandung.: Himpunan Ikatan Sarjana dan Pemerhati Pendidikan IPA Indonesia Bekerjasama dengan FPMIPA Universitas Pendidikan Indonesia,

Sa'diyah, H. (2014). Pengembangan Perangkat Pembelajaran Berbasis Guided Inquiry pada Materi Limbah untuk Meningkatkan Hasil Belajar Siswa SMK. (Tesis magister pendidikan tidak dipublikasikan). Universitas Negeri Surabaya.

Schwarz, C.V. \& Gwekwerere, Y,N. (2006). "Using a Guided Inquiry and Modeling Instructional Framework (EIMA) to Support Presevice K-8 Science Teaching”. Journal Online Wiley Periodicals, Inc. Sci Ed 91:158-186. http://onlinelibrary.wiley.com/doi/10.1002/sce.2 0177/ pdf. Diakses tanggal 29 September 2014.

Slavin, R.E. (2006). Education Psychology: Theory and Practice. Boston: Pearson Education, Inc.

Tuckman, B.W. (1978). Conducting Educational Research. New York: Harcourt Brace Jovanovich Publishers.

Woolfolk, A. (2009). Educational Psychology Active Learning Edition: Edisi Kesepuluh Bagian Kedua. Yogyakarta: Pustaka Pelajar. 